\title{
High astigmatism induced by scleromalacia perforans
}

Tryfon Rotsos*, Konstantinos Andreanos, Anna-Maria Sideri, Ilias Georgalas, Konstantinos Droutsas, Dimitrios Brouzas and Dimitrios Papaconstantinou

Ophthalmology Department, University of Athens, Athens, Greece

\begin{abstract}
We present a case of scleromalacia perforans in an 80-year-old woman. Her vision has deteriorated over the last two years due to progressive astigmatism induced by sclerocorneal thinning.
\end{abstract}

\section{Introduction}

Scleromalacia perforans is a rare entity (4\% of scleritis) that is commonly seen in patients with rheumatoid arthritis with extraarticular presentation, especially women [1]. It is characterized by a non-inflammatory, often bilateral progressive scleral thinning which can lead to a lack of scleral tissue revealing bare uvea. It has also been described in a number of collagen and vasculitic disorders such as Wegener's granulomatosis [1], Bechet disease [2] and ankylosing spondylitis [3].

\section{Case report}

We present an 80-year-old woman with no previous systemic pathology, presented with bilateral progressive visual loss over the last two years. Her last ophthalmological examination was after uneventful cataract surgery in both eyes, two years ago. No serious pathology was recorded, and her uncorrected visual acuity was 20/25 in both eyes.

During our examination, visual acuity was count fingers in both eyes which would improve to $20 / 40$ with $-5.00 \mathrm{cyl} \times 100^{\circ}$ in the right eye and $-5.00 \mathrm{cyl} \times 110^{\circ}$ in the left eye. Slit lamp examination revealed nasal and temporal scleral thinning with uveal show under a thin conjunctival layer (Figure 1A). Moreover, corneal thinning was observed in both the temporal and nasal limbus (Figure 1B) along with the presence of horizontal corneal striae extending throughout the cornea (Figure 1C). Anterior Segment Optical Coherence Tomography confirmed the absence of scleral tissue and the diagnosis of scleromalacia perforans (Figure 1D). The patient was referred for systemic evaluation in which rheumatoid arthritis was diagnosed.

\section{Conclusion}

Scleromalacia perforans is a severe eye disorder with insidious onset, slow progression [1,2]. Visual loss can occur due to progressive high astigmatism, cataract, glaucoma or globe rupture (usually following trauma) $[1,2]$. No therapy has yet proven efficient and patients

Copyright: (C2019 Rotsos T. This is an open-access article distributed under the terms of the Creative Commons Attribution License, which permits unrestricted use, distribution, and reproduction in any medium, provided the original author and source are credited.

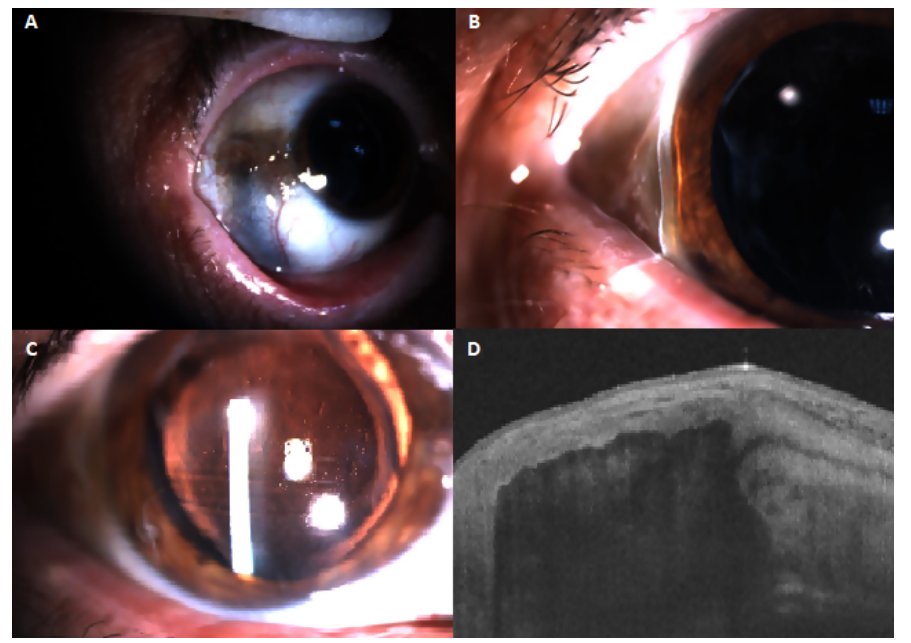

Figure 1 A-D. 1A. Slit lamp examination of patient with sleromalacia perforans showing scleral thinning and uveal show. 1B. Same patient's slit lamp examination revealing cornea thinning at the temporal limbus.1C. Horizontal cornea striae extending throughout the cornea. 1D. Anterior segment optical coherence tomography revealing absence of scleral tissue

should be warned of globe rupture risk [1]. Eye care specialists should be aware of the induction of progressive astigmatism in patients with scleromalacia perforans.

\section{References}

1. Reddy SC, Tajunisah I, Rohana T (2011) Bilateral scleromalacia perforans and peripheral corneal thinning in Wegener's granulomatosis. Int J Ophthalmol 4: 439442. [Crossref]

2. Sakellariou G, Berberidis C, Vounotrypidis P (2005) A case of Behcet's disease with scleromalacia perforans. Rheumatology (Oxford) 44: 258-260. [Crossref]

3. Elkhoyaali A, Elasri F, Khmamouch M, Massoudi R, Reda K, et al. (2015) Scleromalacia perforans secondary to ankylosing spondylitis: A case report. $J \mathrm{Fr}$ Ophtalmol 38: e159-61. [Crossref]

*Correspondence to: Tryfon Rotsos, 15 Alkmanos street, Athens, Greece, 11528; Tel: +306974727279; E-mail: tryfonrotsos@hotmail.com

Key words: scleromalacia perforans, cornea thinning, astigmatism

Received: January 23, 2019; Accepted: February 11, 2019; Published: February 14,2019 